\title{
Role of epoxide hydrolases in lipid metabolism
}

\author{
Christophe Morisseau \\ Department of Entomology and U.C.D. Comprehensive Cancer Center, One Shields Avenue, \\ University of California, Davis CA 95616, U.S.A.
}

\begin{abstract}
Epoxide hydrolases (EH), enzymes present in all living organisms, transform epoxide-containing lipids to 1,2-diols by the addition of a molecule of water. Many of these oxygenated lipid substrates have potent biological activities: host defense, control of development, regulation of blood pressure, inflammation, and pain. In general, the bioactivity of these natural epoxides is significantly reduced upon metabolism to diols. Thus, through the regulation of the titer of lipid epoxides, EHs have important and diverse biological roles with profound effects on the physiological state of the host organism. This review will discuss the biological activity of key lipid epoxides in mammals. In addition, the use of EH specific inhibitors will be highlighted as possible therapeutic disease interventions.
\end{abstract}

\section{Keywords}

epoxide hydrolase; epoxy-fatty acids; cholesterol epoxide; juvenile hormone

\section{Introduction}

Epoxides are three atom cyclic ethers formed by the oxidation of olefins. Because of their highly polarized oxygen-carbon bonds and strained ring, epoxides are in general quite reactive with nucleophiles [1]. Reactive epoxides have been reported to have mutagenic, toxic and carcinogenic effects following reaction with critical biological targets such as DNA and proteins [2]. Epoxides produced from endogenous olefins have been detected in all kinds of organisms, from microorganisms to plants and animals. Few examples of these natural epoxides are given in Fig. 1A. Besides a few examples [3], these epoxides are in general relatively stable at physiological conditions [4],[5], and thus do not present an acute danger to cells and organisms. Nevertheless, they need to be transformed in a controlled manner.

For most natural epoxides, catalytic addition of water to yield 1,2-diols is the main route of metabolism in vivo. This reaction is catalyzed by a family of enzymes called epoxide hydrolases (EHs, EC 3.3.2.6-11) [6],[7]. The reaction is energetically favorable, with water as the only co-substrate [8]. Besides a few exceptions, all the EHs described, from bacteria to mammals, are members of the $a, \beta$-fold hydrolase family of enzymes that also includes

(C) 2012 Elsevier Masson SAS. All rights reserved.

Address correspondence to: Christophe Morisseau, Department of Entomology, University of California at Davis, One Shields Avenue, Davis, CA 95616. Tel: 530752 6571, Fax: 530-751-1537, chmorisseau@ucdavis.edu.

Publisher's Disclaimer: This is a PDF file of an unedited manuscript that has been accepted for publication. As a service to our customers we are providing this early version of the manuscript. The manuscript will undergo copyediting, typesetting, and review of the resulting proof before it is published in its final citable form. Please note that during the production process errors may be discovered which could affect the content, and all legal disclaimers that apply to the journal pertain. 
esterases, and have a common mechanism of action [6],[8]. The EH catalytic cycle involves the formation of a covalent enzyme-substrate intermediate, called hydroxyl alkyl-enzyme, which is subsequently hydrolyzed by a water molecule [8]. Based on this mechanism, transition-state inhibitors of EHs have been designed (Fig. 1B). These ureas and amides are tight-binding competitive inhibitors with low nanomolar dissociation constants $\left(\mathrm{K}_{\mathrm{I}}\right)$ [9],[10]. Such compounds have been found to inhibit EHs from mammals to bacteria as well as in plants and insects [9],[11]-[13], thus representing a useful tool to explore the role of EHs in all these organisms.

While EHs were originally thought to play a role only in epoxide detoxification [7], the fact that endogenous epoxides and EHs are ubiquitously found in nature strongly suggests a role for EHS in the regulation of these natural compounds. Overall, EHs have three main functions: catabolism, detoxification, and regulation of signaling molecules. As the roles of EHs seem to differ profoundly from organism to organism, this review focuses on the current knowledge of the roles of EHs across plant and animal kingdoms.

\section{Role of EH in non-vertebrates}

\section{1 microorganisms}

Epoxide hydrolases are widely spread in microorganisms [14]. They have been reported and studied in bacteria, yeasts and fungi. In most microorganisms, EHs are intracellular and constitutively expressed. In a few cases, EH activity is important for the metabolism of carbon-sources of natural-(such as limonene oxide 1 (compound $\mathbf{1}$ in Fig. 1A)) or artificial(such as epichlorohydrin) origin [15],[16]. Interestingly, the crystal structure of Rhodococcus erythropolis limonene-1,2-epoxide hydrolase revealed that it is an unusual EH. It is not an $\alpha, \beta$-fold hydrolase and it has a one-step catalytic mechanism [17]. Some fungal EHs seems important in the synthesis of mycotoxins [18],[19]. However, in most cases biological function of microbiological EHs is unknown. In fact, most microbial EHs are studied for their application in bio-organic synthesis of enantiomerically pure epoxides or diols [20]. However, some bacterial EHs may have a role in human health. Mycobacterium tuberculosis has at least six active EHs, which may be important in the lung infection caused by this bacterium [21]. Some of these EHs can hydrolyze epoxy-fatty acids (e.g. 4) and cholesterol 5,6-oxide 2, which are endogenous cell signaling molecules in mammals [2],[6]. In Pseudomonas aeruginosa, another lung pathogen, the virulence factor Cif (cystic fibrosis transmembrane conductance regulator inhibitory factor) that has the same biology as cystic fibrosis at the cellular level, was recently shown to be a catalytically active EH [22]. Interestingly, structure analysis revealed that this latter bacterial EH has a non-canonical His/Tyr ring-opening pair instead of the classical tyrosine pair (Fig. 1B) [23]. While it is still unknown, the target substrate for Cif is probably a human lipid epoxide.

\subsection{Plants}

Epoxide hydrolases have been reported and characterized from numerous plants (reviewed in [6]). There is evidence that plants contain multiple EH isoforms, which seems to be expressed constitutively or induced by pathogen infections or hormones involved in host defense [24]-[26]. The tissue distribution of EHs is quite variable from plant to plant; EHs have been localized in germinated seeds, seedlings, roots, fruit, tubers, and leaves [6]. Numerous epoxide containing lipids, especially from fatty acids, are associated with host defense responses [27] and cutin polymer synthesis [28]. Such epoxy-fatty acids, especially those of linoleic acid, seem to be the preferred endogenous substrates of plant EHs [6]. Thus, current knowledge points to a role of EHs in plant defenses and more generally in response to stress, both in passive (cutin biosynthesis) and active (anti-fungal chemical 
synthesis or defense regulation/signaling) ways. However, this is quite speculative, and reflects an overall lack of knowledge of the plant EHs.

\subsection{Insects}

In invertebrate animals, EHs have mostly been studied in insects for their roles in the metabolism of xenobiotics, juvenile hormones and pheromones. Studying insect resistance, insect EHs were shown to play an essential role in the metabolism of cyclodiene insecticides (reviewed in [7]). EHs have also been hypothesized to metabolize the epoxide functionalities common among plant natural products that are found in herbivorous insects' diet [29]. However, little is known in this area of insect physiology. In fact, EHs in insects are mostly studied for their involvement in the metabolism of juvenile hormone (3 Fig. 1A). This terpenic hormone regulates the maturation of insects, reproduction, behavior, coloration, diapause, and other biologies [30]. JH titer is regulated not only by its biosynthesis, but also by its metabolism and possibly by its sequestration. $\mathrm{JH}$ is primarily metabolized by two hydrolytic enzymes known as JH esterase (JHE) and JH epoxide hydrolase (JHEH) [30]. Recent evidence shows that JHEH is certainly different from the insect EHs responsible for xenobiotic metabolism [7]. In fact, JHEH seems very specific for the juvenile hormones. The relative role of epoxide hydration and ester hydrolysis in JH catabolism vary with species and insect life stage [30],[31]. Potent selective inhibitors active in vivo have been used to demonstrate the profound biological effects of JHE in insects [32]. While attempts have been made to produce potent inhibitor for the JHEH [13], similar experiments to test how critical JHEH is in insect developmental biology have not yet been run. Finally, some insect pheromones, such as disparlure from the gypsy moth (Lymantria dispar), have an epoxide on a hydrocarbon backbone. Rapid degradation of a pheromone following its initial detection is critical for the insect to orient itself in a dynamic way. For compounds like disparlure, some EHs can play this role in the insect antenna [33]. Recently, an EH that hydrolyzes the epoxide of vernolic acid was shown to be involved in the biosynthesis of a pheromone in the jewel wasp Nasonia vitripennis [34].

\section{Role of EH in mammals}

In vertebrate animals, EHs have mostly been studied in mammals, which is the subject of this section. In general, the roles of EHs in lower chordates are expected to be similar to the ones in mammals, however differences certainly exist. Based on activity, sub-cellular location, and DNA sequence, eight potential EHs were reported in mammals (Table 1). While put in this listing, the leukotriene $\mathrm{A}_{4}$ hydrolase $\left(\mathrm{LTA}_{4} \mathrm{H}\right.$; EC 3.3.2.6) is an atypical $\mathrm{EH}$; it is a bi-functional zing metalloprotein, which displays both epoxide hydration and aminopeptidase activities at the same catalytic site [35]. It has been recently well reviewed [36], and will not be addressed here. The Hepoxilin EH was first isolated from rat liver cytosol and described as different from the soluble epoxide hydrolase (sEH) based on apparent molecular weight and activity for hepoxilin $\mathrm{A}_{3} \mathbf{5}$ [37]. However, a recent study showed that sEH is identical to the hepoxilin EH [38]. The paternally expressed gene 1 (peg1/MEST) is a mesoderm-specific imprinted gene widely expressed in mammalian tissues [2]. Sequence similarity suggests it is a $\alpha / \beta$-fold epoxide hydrolase [39]. However, to date no EH activity has been reported for peg1/MEST. Interestingly, sequence alignment suggests peg1/MEST has only one tyrosine in the active site to activate the epoxide ring instead of two for classical EHs (Fig. 1B) [39]. Recently, an EH from Pseudomonas aeruginosa with only one tyrosine in the active site was shown to be a catalytically active EH [22]. Such structural feature defines a distinct class of $\alpha / \beta$ epoxide hydrolases that seem to have a very slow turnover rate [23]. Recent genome analysis has revealed two new possible epoxide hydrolases in mammals: EH3 and EH4 [2]. However, no data on their activity or substrate specificity has yet been published. 


\subsection{Microsomal epoxide hydrolase ( $\mathrm{mEH})$}

The mEH (EC 3.3.2.9) was first identified in the metabolism of polyaromatic compounds.

Since then it has been recognized as a key enzyme in the metabolism of numerous xenobiotics in vitro and in vivo (recently reviewed in [2],[6],[7]). As most resulting diols are less toxic or mutagenic than the starting epoxide, $\mathrm{mEH}$ is generally considered cytoprotective and its inhibition is not desired [7]. As expected for an enzyme with such role in xenobiotic metabolism, $\mathrm{mEH}$ has a very broad substrate selectivity and is expressed prominently in the liver [6]. While its role in the metabolism of environmental contaminants is well documented, little is known about $\mathrm{mEH}$ action on endogenous epoxides. Some steroid epoxides, such as estroxide or androstene oxide $\mathbf{6}$, have been suggested as endogenous substrates [40]. However, mEH action on these lipid epoxides has yet to be demonstrated in vivo. Epoxy-fatty acids, such as 14,15-epoxyeicosatrienoic acid 4, are also substrates for $\mathrm{mEH}$ in vitro [6],[41]. However, determination of kinetic constants has revealed that the sEH hydrolyzes epoxy-fatty acids around 100-fold faster than the $\mathrm{mEH}$ [41]. Thus, based on the abundance of the $\mathrm{sEH}$ relative to the $\mathrm{mEH}$ in most tissues such as liver [6], and the low efficiency of $\mathrm{mEH}$ with these kind of substrates, the $\mathrm{mEH}$ certainly has a minor contribution in the metabolism of epoxy-fatty acids in vivo [2],[7]. However, in the case of therapeutic inhibition of the sEH and in organs with high levels of $\mathrm{mEH}$ such as some brain regions [41], the $\mathrm{mEH}$ may contribute significantly to the hydration of some epoxy-fatty acids. Finally, $\mathrm{mEH}$ was reported to play a role in hepatic bile acid transport [42]. However, the mechanism by which $\mathrm{mEH}$ participates in bile acid transport is unknown.

\subsection{Cholesterol epoxide hydrolase (ChEH)}

While the enzymatic hydrolysis of 5,6-epoxy-cholesterol 2 was described in the midseventies, it was only in the mid-eighties that ChEH (EC 3.3.2.11) was shown to be different from $\mathrm{mEH}$ as both enzymes are membrane bound and express in the same tissues [43]. However, in contrast to the $\mathrm{mEH}, \mathrm{ChEH}$ is very specific for the hydrolysis of 5,6-epoxycholesterol 2, and, in tissue extracts, it prefers the alpha- over the beta-diastereomer [6]. Furthermore, $\mathrm{ChEH}$ is the only mammalian $\mathrm{EH}$ known to act on this very unreactive epoxide [5]. ChEH is probably not an $\alpha, \beta$-fold hydrolase as no covalent intermediate with it substrate was isolated [44]. The $\mathrm{ChEH}$ was recently identified as a hetero-oligomeric complex composed partially of a steroid-isomerase (D8D7I) and a steroid-reductase (DHCR7) [45]. This complex is also known as the microsomal antiestrogen binding site (AEBS). Interestingly, the $\mathrm{mEH}$ also seems to be part of the AEBS complex [46]. While the biological role of ChEH is not known, it's action in the metabolism of 5,6-epoxycholesterol 2 and reported action of AEBS suggest biological roles of ChEH in homeostasis, lipid synthesis and breast cancer resistance to tamoxifen [45]. The identification of ChEH has paved the way to the development of chemical and molecular tools to understand the role of ChEH.

\subsection{Soluble epoxide hydrolase (sEH)}

The mammalian sEH (EC 3.3.2.10) is a $120 \mathrm{kDa}$ dimer of two identical $62.5 \mathrm{kDa}$ monomers arranged in an anti-parallel fashion. It is mostly expressed in the liver, kidneys, brain, endothelium, and at lesser levels in other tissues [6]. While mostly found in the cytosol, in some tissues a significant part of the activity is also found in the peroxisomes. Interestingly, each sEH monomer has two catalytic activities: an epoxide hydrolysis activity in the Cterminal domain, and a magnesium dependent lipid phosphate ester hydrolysis activity in the $\mathrm{N}$-terminal domain (EC 3.1.3.76) [47]. Recently, this phosphatase activity was shown to hydrolyze lysophosphatidic acids efficiently [48]. Here, we are concentrating on the epoxide hydrolysis activity of sEH. 
Like the $\mathrm{mEH}$, the sEH was first investigated for its ability to metabolize xenobiotics. While $\mathrm{sEH}$ is capable in vitro of degrading some xenobiotic epoxides, $\mathrm{sEH}$ has not been shown to be involved in the metabolism of potent toxic, carcinogenic or mutagenic epoxides in vivo [2],[6],[7]. In fact, epoxy-fatty acids, such as 14,15-epoxyeicosatrienoic acid 4, are the preferred lipid substrates for the sEH . Interestingly, sEH hydrolyzes such epoxides 100-fold faster than other mammalian EHs [41]. Both n-3 and n-6 epoxy-fatty acids are excellent substrates for the sEH [49]. These epoxy-fatty acids have broad activities as both autocrine and paracrine chemical mediators involved in many biologies [2],[50]. Through the development of potent selective inhibitors for sEH (structure and efficacy recently reviewed in [10]), it is possible to stabilize in vivo levels of these endogenous lipid epoxides. Pharmacological inhibition of sEH has resulted in anti-hypertensive, anti-inflammatory, neuroprotective and cardioprotective effects as well as pain reduction [2],[7],[50]. The reduction in hypertension by sEH inhibitors (sEHI) is associated with elevated levels of epoxy-fatty acids that regulate blood pressure by acting on the vascular tone in small resistance arteries and by enhancing natriuresis in the kidney [50],[51].

Inflammation and pain are major components of many disease states. The anti-inflammatory activities of sEHIs (AUDA-BE in Fig. 2) occur in part through the NF- $\kappa$ B mediated downregulation of cyclooxygenase-2 (COX2) transcription, resulting in lower production of proinflammatory prostaglandins such as $\mathrm{PGE}_{2}$ and $\mathrm{PGD}_{2}$ [50],[52]. As expected from these results, sEHIs synergize with classical COX2 inhibitors (coxibs, e.g. celecoxib in Fig. 2) to reduce inflammation even more. Through the selective inhibition of COX2, coxibs increase cardiovascular risk (particularly in individuals with low nitric oxide) by changing the prostacyclin/thromboxane ratio. Interestingly, co-treatment with sEHI normalizes this PGI// TXA2 ratio [50],[52]. Thus combinations of sEHI with coxibs enhance potency while reducing the dose and side effects. A similar effect was observed with other antiinflammatory drugs [50],[53]. In addition, the stabilization of epoxy-fatty acids by sEHI represents a novel way to treat numerous diseases in which chronic inflammation is a major component, such as atherosclerosis and end organ damage [50],[54].

While sEH inhibition does not alter pain perception in healthy animals, it reduces both inflammatory and neuropathic pains in animal models [55]. The effectiveness of the sEHIs in both kinds of pain is associated with elevated levels of epoxy-fatty acids, suggesting a common mechanism of action [55]. Interestingly, epoxides from both $\omega-3$ and $\omega-6$ fatty acids are efficient in reducing inflammatory pain (Fig. 3), while the corresponding fatty acids are inefficient [49]. Larger and longer effects are observed when the epoxy-fatty acids are co-treated with sEH inhibitors [55]. In addition, regioisomers of DHA epoxides have unequal effects on inflammatory pain (Fig. 3 insert) [49], suggesting that complex balances between all the epoxy-fatty acids are at the origin of the observed effects. Nevertheless, overall increasing epoxy-fatty acids concentrations with sEH inhibitors has many beneficial effects from reducing pain perception, inflammation and cardiovascular disease [50]. However, sEH inhibition might have some undesired effects, because epoxides of arachidonic acid were recently shown to have carcinogenic potential [56].

\section{Conclusion}

Over the past decade, endogenous lipid epoxides have emerged as key cell signaling molecules involved in numerous biologies. In many organisms, EHs play a central role in regulating the levels of lipid epoxides, and EH inhibition can influence physiological and pathological conditions. For example, mammalian sEH inhibition reduces blood pressure, inflammation and pain by stabilizing P-450 generated epoxy-fatty acids. These observations point to an essential role of EHs in human health, and the possibility of different yet important roles in other organisms. 


\section{Acknowledgments}

This work was partially funded by NIEHS Superfund Basic Research and Program P42 ES04699.

\section{Abbreviations}

Cif cystic fibrosis trans-membrane conductance regulator inhibitory factor

COX2 cyclooxygenase-2

EH epoxide hydrolase

JHE juvenile hormone esterase

LTA 4 leukotriene $\mathrm{A}_{4}$ hydrolase

\section{References}

1. Parker RE, Isaacs NS. Mechanism of epoxide reactions. Chem. Rev. 1959; 264:9310-9313.

2. Decker M, Arand M, Cronin A. Mammalian epoxide hydrolases in xenobiotic metabolism and signaling. Arch. Toxicol. 2009; 83:297-318. [PubMed: 19340413]

3. Fulton D, Falck JR, McGiff JC, Carroll MA, Quilley J. A method for the determination of 5,6-EET using the lactone as an intermediate in the formation of the diol. J. Lipid Res. 1998; 39:1713-1721. [PubMed: 9717733]

4. Newman JW, Hammock BD. Optimized thiol derivatizing reagent for the mass spectral analysis of disubstituted epoxy fatty acids. J. Chromatogr. A. 2001; 925:223-240. [PubMed: 11519808]

5. Paillasse MR, Saffon N, Gornitzka H, Silvente-Poirot S, Poirot M, de Medina P. Surprising 'un' Reactivity of Cholesterol-5,6-Epoxides Towards Nucleophiles. J. Lipid Res. 2012; 53:718-725. [PubMed: 22285872]

6. Newman JW, Morisseau C, Hammock BD. Epoxide hydrolases: their roles and interactions with lipid metabolism. Prog. Lipid Res. 2005; 44:1-51. [PubMed: 15748653]

7. Morisseau C, Hammock BD. Gerry Brooks and epoxide hydrolases: four decades to a pharmaceutical. Pest. Manag. Sci. 2008; 64:594-609. [PubMed: 18383502]

8. Morisseau C, Hammock BD. Epoxide hydrolases: mechanisms, inhibitor designs, and biological roles. Annu. Rev. Pharmacol. Toxicol. 2005; 45:311-333. [PubMed: 15822179]

9. Morisseau C, Goodrow MH, Dowdy D, Zheng J, Greene JF, Sanborn JR, Hammock BD. Potent urea and carbamate inhibitors of soluble epoxide hydrolases. Proc. Natl. Acad. Sci. USA. 1999; 96:8849-8854. [PubMed: 10430859]

10. Shen HC, Hammock BD. Discovery of Inhibitors of Soluble Epoxide Hydrolase: A Target with Multiple Potential Therapeutic Indications. J. Med. Chem. 2012; 55:1789-1808. [PubMed: 22168898]

11. Biswal BK, Morisseau C, Garen G, Cherney MM, Garen C, Niu C, Hammock BD, James MN. The molecular structure of epoxide hydrolase B from Mycobacterium tuberculosis and its complex with a urea-based inhibitor. J. Mol. Biol. 2008; 381:897-912. [PubMed: 18585390]

12. Morisseau C, Beetham JK, Pinot F, Debernard S, Newman JW, Hammock BD. Cress and potato soluble epoxide hydrolases: purification, biochemical characterization, and comparison to mammalian enzymes, Arch. Biochem. Biophys. 2000; 378:321-332. [PubMed: 10860549]

13. Severson TF, Goodrow MH, Morisseau C, Dowdy DL, Hammock BD. Urea and amide-based inhibitors of the juvenile hormone epoxide hydrolase of the tobacco hornworm (Manduca sexta: Sphingidae). Insect Biochem. Mol. Biol. 2002; 32:1741-1756. [PubMed: 12429126]

14. van Loo B, Kingma J, Arand M, Wubbolts MG, Janssen DB. Diversity and biocatalytic potential of epoxide hydrolases identified by genome analysis. Appl. Environ. Microbiol. 2006; 72:29052917. [PubMed: 16597997]

15. van der Werf MJ, Swarts HJ, de Bont JA. Rhodococcus erythropolis DCL14 contains a novel degradation pathway for limonene. Appl. Environ. Microbiol. 1999; 65:2092-2102. [PubMed: 10224006] 
16. Jacobs MH, Van den Wijngaard AJ, Pentenga M, Janssen DB. Characterization of the epoxide hydrolase from an epichlorohydrin-degrading Pseudomonas sp . Eur. J. Biochem. 1991; 202:12171222. [PubMed: 1662605]

17. Arand M, Hallberg BM, Zou J, Bergfors T, Oesch F, van der Werf MJ, de Bont JA, Jones TA, Mowbray SL. Structure of Rhodococcus erythropolis limonene-1,2-epoxide hydrolase reveals a novel active site. EMBO J. 2003; 22:2583-2592. [PubMed: 12773375]

18. Morisseau C, Ward BL, Gilchrist DG, Hammock BD. Multiple epoxide hydrolases in Alternaria alternata f. sp. lycopersici and their relationship to medium composition and host-specific toxin production. Appl. Environ. Microbiol. 1999; 65:2388-2395. [PubMed: 10347018]

19. Bradshaw RE, Zhang S. Biosynthesis of dothistromin. Mycopathologia. 2006; 162:201-213. [PubMed: 16944287]

20. Kotik M, Archelas A, Wohlgemuth R. Epoxide hydrolases and their application in organic synthesis. Curr. Org. Chem. 2012; 16:451-482.

21. Johansson P, Unge T, Cronin A, Arand M, Bergfors T, Jones TA, Mowbray SL. Structure of an atypical epoxide hydrolase from Mycobacterium tuberculosis gives insights into its function. J. Mol. Biol. 2005; 351:1048-1056. [PubMed: 16051262]

22. Bahl CD, Morisseau C, Bomberger JM, Stanton BA, Hammock BD, O'Toole GA, Madden DR. Crystal structure of the cystic fibrosis transmembrane conductance regulator inhibitory factor Cif reveals novel active-site features of an epoxide hydrolase virulence factor. J. Bacteriol. 2010; 192:1785-1795. [PubMed: 20118260]

23. Bahl CD, Madden DR. Pseudomonas aeruginosa cif defines a distinct class of $\alpha / \beta$ epoxide hydrolases utilizing a His/Tyr ring-opening pair. Protein \& Peptide Lett. 2012; 19:186-193.

24. Arahira M, Nong VH, Udaka K, Fukazawa C. Purification, molecular cloning and ethyleneinducible expression of a soluble-type epoxide hydrolase from soybean (Glycine max [L.] Merr.). Eur. J. Biochem. 2000; 267:2649-2657. [PubMed: 10785386]

25. Gomi K, Yamamato H, Akimitsu K. Epoxide hydrolase: a mRNA induced by the fungal pathogen Alternaria alternata on rough lemon (Citrus jambhiri Lush). Plant. Mol. Biol. 2003; 53:189-199. [PubMed: 14756316]

26. Wijekoon CP, Goodwin PH, Valliani M, Hsiang T. The role of a putative peroxisomaltargeted epoxide hydrolase of Nicotiana benthamiana in interactions with Colletotrichum destructivum $C$. orbiculare or Pseudomonas syringae pv. tabaci . Plant Sci. 2011; 181:177-187. [PubMed: 21683883]

27. Kachroo A, Kachroo P. Fatty Acid-derived signals in plant defense. Annu. Rev. Phytopathol. 2009; 47:153-176. [PubMed: 19400642]

28. Li Y, Beisson F. The biosynthesis of cutin and suberin as an alternative source of enzymes for the production of bio-based chemicals and materials. Biochimie. 2009; 91:685-691. [PubMed: 19344744]

29. Mullin CA. Adaptive relationships of epoxide hydrolase in herbivorous arthropods. J. Chem. Ecol. 1988; 14:1867-1888.

30. Goodman, WG.; Cusson, M. The Juvenile Hormones. In: Gilbert, LI., editor. Insect Endocrinology. New York: Academic Press; 2011. p. 310-365.

31. Khlebodarova TM, Gruntenko NE, Grenback LG, Sukhanova MZ, Mazurov MM, Rauschenbach IY, Tomas BA, Hammock BD. A comparative analysis of juvenile hormone metabolyzing enzymes in two species of Drosophila during development. Insect Biochem. Mol. Biol. 1996; 26:829-835. [PubMed: 9014329]

32. Abdel-Aal YA, Hammock BD. Transition state analogs as ligands for affinity purification of juvenile hormone esterase. Science. 1986; 233:1073-1076. [PubMed: 3738525]

33. Graham SM, Prestwich GD. Tissue distribution and substrate specificity of an epoxide hydrase in the gypsy moth Lymantria dispar. Experientia. 1992; 48:19-21.

34. Abdel-Latief M, Garbe LA, Koch M, Ruther J. An epoxide hydrolase involved in the biosynthesis of an insect sex attractant and its use to localize the production site. Proc. Natl. Acad. Sci. USA. 2008; 105:8914-8919. [PubMed: 18579785] 
35. Rudberg PC, Tholander F, Thunnissen MM, Haeggström JZ. Leukotriene A4 hydrolase/ aminopeptidase. Glutamate 271 is a catalytic residue with specific roles in two distinct enzyme mechanisms. J Biol. Chem. 2002; 277:1398-1404. [PubMed: 11675384]

36. Rinaldo-Matthis A, Haeggstroem JZ. Structures and mechanisms of enzymes in the leukotriene cascade. Biochimie. 2010; 92:676-681. [PubMed: 20097252]

37. Pace-Asciak CR, Lee WS. Purification of hepoxilin epoxide hydrolase from rat liver. J. Biol. Chem. 1989; 264:9310-9313. [PubMed: 2722835]

38. Cronin A, Decker M, Arand M. Mammalian soluble epoxide hydrolase is identical to liver hepoxilin hydrolase. J. Lipid Res. 2011; 52:712-719. [PubMed: 21217101]

39. Kaneko-Ishino T, Kuroiwa Y, Miyoshi N, Kohda T, Suzuki R, Yokoyama M, Viville S, Barton SC, Ishino F, Surani MA. Peg1/Mest imprinted gene on chromosome 6 identified by cDNA subtraction hybridization. Nat. Genet. 1995; 11:52-59. [PubMed: 7550314]

40. Fändrich F, Degiuli B, Vogel-Bindel U, Arand M, Oesch F. Induction of rat liver microsomal epoxide hydrolase by its endogenous substrate 16 alpha 17 alpha-epoxyestra- 1,3,5-trien-3-ol. Xenobiotica. 1995; 25:239-244. [PubMed: 7618350]

41. Marowsky A, Burgener J, Falck JR, Fritschy JM, Arand M. Distribution of soluble and microsomal epoxide hydrolase in the mouse brain and its contribution to cerebral epoxyeicosatrienoic acid metabolism. Neuroscience. 2009; 163:646-661. [PubMed: 19540314]

42. Alves C, von Dippe P, Amoui M, Levy D. Bile acid transport into hepatocyte smooth endoplasmic reticulum vesicles is mediated by microsomal epoxide hydrolase, a membrane protein exhibiting two distinct topological orientations. J. Biol. Chem. 1993; 268:20148-20155. [PubMed: 8376374]

43. Oesch F, Timms CW, Walker CH, Guenthner TM, Sparrow A, Watabe T, Wolf CR. Existence of multiple forms of microsomal epoxide hydrolases with radically different substrate specificities. Carcinogenesis. 1984; 5:7-9. [PubMed: 6690087]

44. Müller F, Arand M, Frank H, Seidel A, Hinz W, Winkler L, Hänel K, Blée E, Beetham JK, Hammock BD, Oesch F. Visualization of a covalent intermediate between microsomal epoxide hydrolase, but not cholesterol epoxide hydrolase, and their substrates. Eur. J. Biochem. 1997; 245:490-496. [PubMed: 9151984]

45. de Medina P, Paillasse MR, Segala G, Poirot M, Silvente-Poirot S. Identification and pharmacological characterization of cholesterol-5,6-epoxide hydrolase as a target for tamoxifen and AEBS ligands. Proc. Natl. Acad. Sci. USA. 2010; 107:13520-13525. [PubMed: 20615952]

46. Mésange F, Sebbar M, Kedjouar B, Capdevielle J, Guillemot JC, Ferrara P, Bayard F, Delarue F, Faye JC, Poirot M. Microsomal epoxide hydrolase of rat liver is a subunit of the anti-oestrogenbinding site. Biochem. J. 1998; 334:107-112. [PubMed: 9693109]

47. Newman JW, Morisseau C, Harris TR, Hammock BD. The soluble epoxide hydrolase encoded by EPXH2 is a bifunctional enzyme with novel lipid phosphate phosphatase activity. Proc. Natl. Acad. Sci. USA. 2003; 100:1558-1563. [PubMed: 12574510]

48. Morisseau C, Schebb NH, Dong H, Ulu A, Aronov PA, Hammock BD. Role of soluble epoxide hydrolase phosphatase activity in the metabolism of lysophosphatidic acids. Biochem. Biophys. Res. Commun. 2012; 419:796-800. [PubMed: 22387545]

49. Morisseau C, Inceoglu B, Schmelzer K, Tsai HJ, Jinks SL, Hegedus CM, Hammock BD. Naturally occurring monoepoxides of eicosapentaenoic acid and docosahexaenoic acid are bioactive antihyperalgesic lipids. J. Lipid Res. 2010; 51:3481-3490. [PubMed: 20664072]

50. Imig JD. Epoxides and soluble epoxide hydrolase in cardiovascular physiology. Physiol. Rev. 2012; 92:101-130. [PubMed: 22298653]

51. Sporková A, Kopkan L, Varcabová S, Husková Z, Hwang SH, Hammock BD, Imig JD, Kramer HJ, Cervenka L. Role of cytochrome P-450 metabolites in the regulation of renal function and blood pressure in 2-kidney 1-clip hypertensive rats. Am. J. Physiol. Regul. Integr. Comp. Physiol. 2011; 300:R1468-R1475. [PubMed: 21411763]

52. Schmelzer KR, Inceoglu B, Kubala L, Kim IH, Jinks SL, Eiserich JP, Hammock BD. Enhancement of antinociception by coadministration of nonsteroidal antiinflammatory drugs and soluble epoxide hydrolase inhibitors. Proc. Natl. Acad. Sci. USA. 2006; 103:13646-13651. [PubMed: 16950874]

53. Liu JY, Yang J, Inceoglu B, Qiu H, Ulu A, Hwang SH, Chiamvimonvat N, Hammock BD. Inhibition of soluble epoxide hydrolase enhances the anti-inflammatory effects of aspirin and 5- 
lipoxygenase activation protein inhibitor in a murine model. Biochem. Pharmacol. 2010; 79:880887. [PubMed: 19896470]

54. Ulu A, Davis BB, Tsai HJ, Kim IH, Morisseau C, Inceoglu B, Fiehn O, Hammock BD, Weiss RH. Soluble epoxide hydrolase inhibitors reduce the development of atherosclerosis in apolipoprotein e-knockout mouse model. J. Cardiovasc. Pharmacol. 2008; 52:314-323. [PubMed: 18791465]

55. Wagner K, Inceoglu B, Hammock BD. Soluble epoxide hydrolase inhibition, epoxygenated fatty acids and nociception. Prostaglandins Other Lipid Mediat. 2011; 96:76-83. [PubMed: 21854866]

56. Panigrahy D, Edin ML, Lee CR, Huang S, Bielenberg DR, Butterfield CE, Barnés CM, Mammoto A, Mammoto T, Luria A, Benny O, Chaponis DM, Dudley AC, Greene ER, Vergilio JA, Pietramaggiori G, Scherer-Pietramaggiori SS, Short SM, Seth M, Lih FB, Tomer KB, Yang J, Schwendener RA, Hammock BD, Falck JR, Manthati VL, Ingber DE, Kaipainen A, D'Amore PA, Kieran MW, Zeldin DC. Epoxyeicosanoids stimulate multiorgan metastasis and tumor dormancy escape in mice. J. Clin. Invest. 2012; 122:178-191. [PubMed: 22182838] 


\section{Highlights}

- Across organisms, endogenous epoxide-containing lipids have potent biological activities.

- Epoxide hydrolases (EH) play a central role in regulating the levels of lipid epoxides.

- EH inhibition can influence physiological and pathological conditions.

- Specifically, mammalian sEH inhibition reduces blood pressure, inflammation and pain. 
A<smiles>C=C(C)C1CCC2(C)OC2C1</smiles><smiles>CC(C)CCC[C@H](C)[C@H]1CC[C@H]2[C@H]3CC4OC45C[C@H](O)CC[C@]3(C)[C@H]5CC[C@]21C</smiles><smiles>COC(=O)/C=C(\C)CC/C=C(\C)CCC1OC1(C)C</smiles>

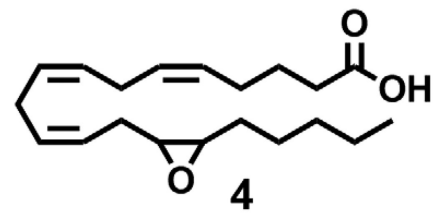<smiles>CCCCCC/C=C/CC1(CC/C=C\CC(O)/C=C\C2CO2)CO1</smiles><smiles>CC12CCC(=O)C=C1CCC1C2CCC2(C)C1CC1OC12</smiles><smiles>CCCCC/C=C\C/C=C\C=C\C=C\C1OC1CCCC(=O)O</smiles>

B

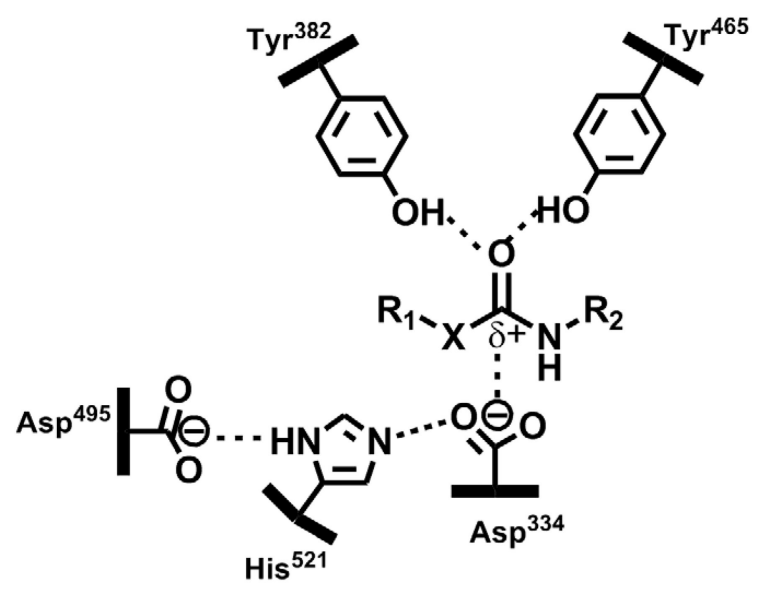

\section{$X: \mathrm{NH}, \mathrm{NR}_{3}, \mathrm{CH}_{2}, \mathrm{O}, \mathrm{S}$.}

Fig. 1.

A. Structure of few natural lipid epoxides: 1 1,2-epoxy-limonene; 2 5,6-epoxy-cholesterol; 3 juvenile hormone III; 4 14,15-epoxy-eicosatrienoic acid; 5: hepoxilin $\mathrm{A}_{3} ; \mathbf{6}$ : androstene-16, (17)-oxide; 7: leukotriene $\mathrm{A}_{4}$. B: Generic structure of non-epoxide based EH inhibitors bound to the active site of the enzyme. The amino acid residue numbers correspond to the human $\mathrm{sEH}$. 


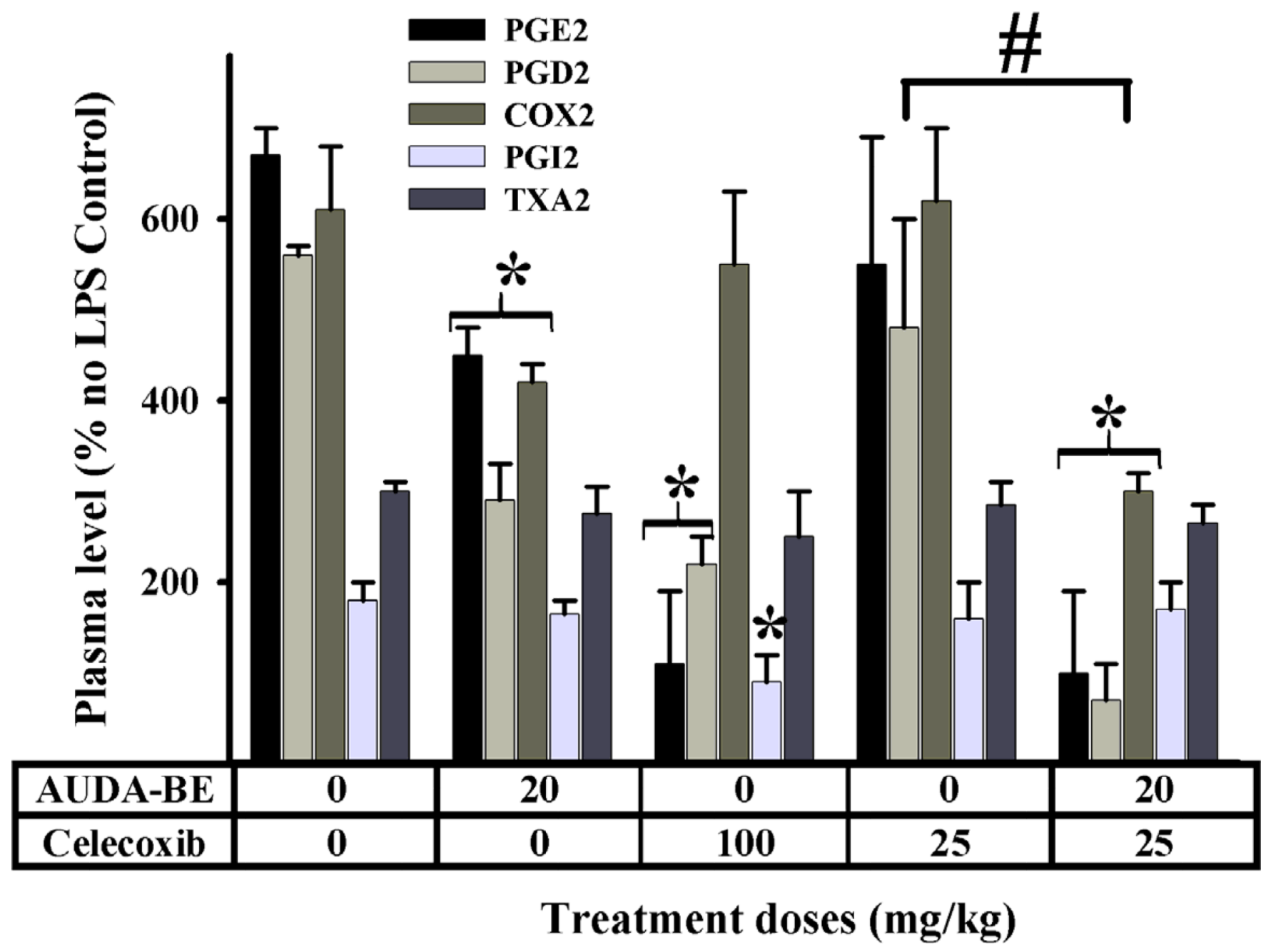

Fig. 2.

Effect of inhibitors of sEH (AUDA-BE) and COX2 (celecoxib) in a LPS induced inflammatory model in mice $(n=4)$; data from [52]. As expected, all inhibitors individually decreased significantly prostaglandins $(* \mathrm{p}<0.05)$. Co-administration of AUDA-BE and a non-optimal dose of celecoxib produces a synergistic decrease in pro-inflammatory prostaglandin (PGD2 and PGE2), and hepatic expression of COX-2 $6 \mathrm{~h}$ after LPS exposure. This decrease is significantly stronger $(\# \mathrm{p}<0.05)$ than celecoxib alone. High doses of celecoxib generate an imbalance in the PGI 2 and TXA 2 concentrations $6 \mathrm{~h}$ after LPS exposure, leading to increased risk of thrombotic events. Co-administration of AUDA-BE and celecoxib does not appear to create this disparity. 


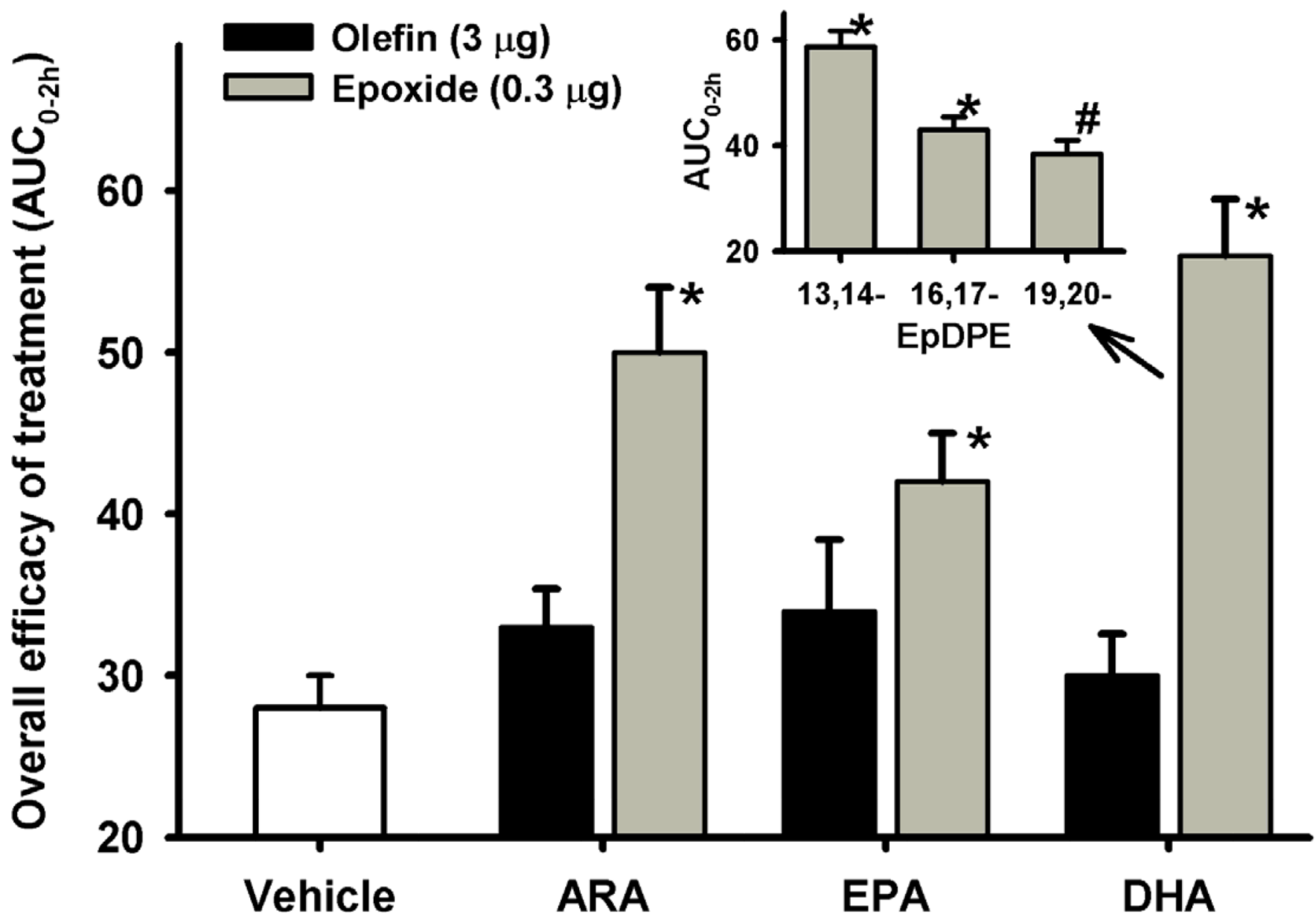

Fig. 3 .

Epoxy-fatty acids but not parent fatty acids reduce mechanical pain withdrawal threshold associated with inflammation induced by a single intraplantar injection of $0.5 \mathrm{mg}$ of carrageenan in rat paws ( $\mathrm{n}=6$ per group); data from [49]. The area under the curve (integrated from 0-120 minutes), which gives an overall measurement of the efficacy of a treatment, is reported on the y-axis. Compared to the vehicle control (10\% ethanol in saline), the mixture of epoxy-fatty acids significantly reduced the pain $(*: p<0.001)$. Insert: Individual DHA epoxide (EpDPE: epoxy-docosapentaenoic acid) regioisomers (300 ng / paw) significantly reduced pain $(*, p<0.001, \#, p=0.03$, compared to the vehicle). 16, 17 EpDPE and 19,20-EpDPE were similar in efficacy $(\mathrm{p}=0.29)$, while 13,14-EpDPE was more efficacious than them $(\mathrm{p}<0.01)$. 


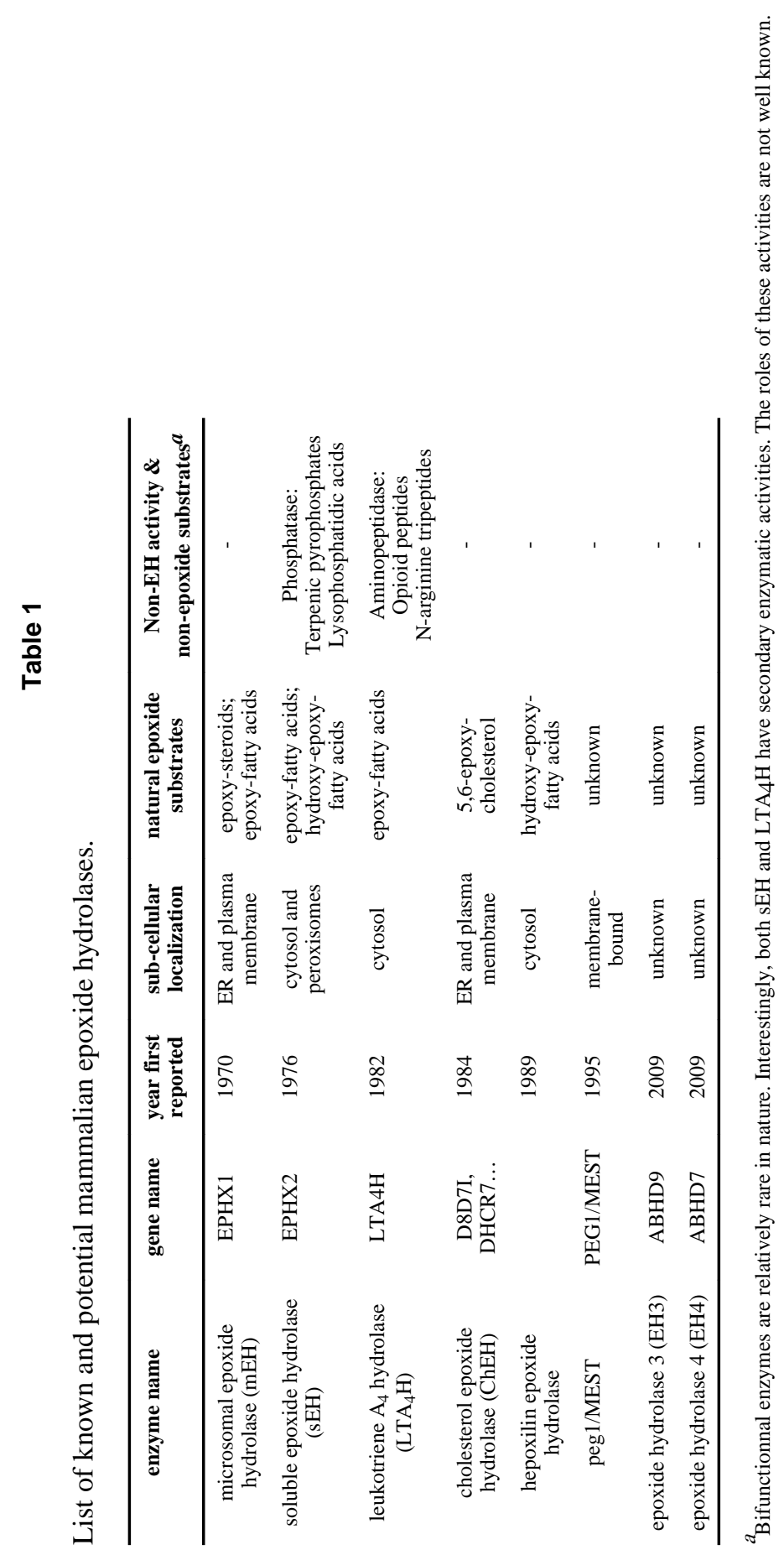

Biochimie. Author manuscript; available in PMC 2014 January 01. 